\title{
ADMINISTRATION OF PLATELET-RICH PLASMA OR CONCENTRATED BONE MARROW ASPIRATE AFTER MECHANICALLY INDUCED ISCHEMIA IMPROVES BIOCHEMICAL PARAMETERS IN SKELETAL MUSCLE
}

\author{
A. T. PIDLISETSKY', G. V. KOSIAKOVA' ${ }^{2}$ T. M. GORIDKO', A. G. BERDYSCHEV ${ }^{2}$ \\ O. F. MEGED $D^{2}$, S. I. SAVOSKO ${ }^{3 凶}$, O. V. DOLGOPOLOV \\ ${ }^{1}$ Lviv Regional Hospital for War Veterans and Repressed named after Yu. Lypa, Ukraine; \\ ${ }^{2}$ Palladin Institute of Biochemistry, National Academy of Sciences of Ukraine, Kyiv; \\ ${ }^{3}$ Bogomolets National Medical University, Kyiv, Ukraine; \\ ${ }^{4}$ SI "Institute of Traumatology and Orthopedics of NAMS of Ukraine", Kyiv; \\ 凶e-mail: savosko_s@ukr.net
}

Received: 16 September 2020; Accepted: 17 May 2021

Ischemia is known to cause structural and functional damage to skeletal muscle. In this research platelet-rich plasma (PRP) and cell bone marrow aspirate (CBMA) which are considered to be promising in regenerative medicine were used to improve the animal muscles condition after ischemia. Mechanically induced ischemia (MII) of the rabbit skeletal muscles was caused by applying a tourniquet to the hind limb for 6 hours. At 6 h after tourniquet was removed the rabbit PRP or CBMA solutions were injected into the tibia muscle and animals were divided into experimental groups $(n=15): 1-i$ schemia + saline, $2-i$ schemia + $P R P, 3-i$ ischemia $+C B M A$. Intact animals were the control group $(n=5)$. Animals were removed from the experiment on 5, 15, and 30 ${ }^{\text {th }}$ days of reperfusion after ischemia. A progressive hypotrophy, muscle fibers destruction and leukocyte infiltration was observed after tibia muscle MII. The ischemic state was accompanied by catalase and superoxide dismutase activation, persistent $\mathrm{NO}_{2}^{-}$overproduction and a significant decrease in glutathione peroxidase activity in the muscle homogenates. It was shown that after PRP or CBMA local injection into the ischemic muscle catalase activity remained at the elevated level, SOD activity approached the control level and the most pronounced effects were $\mathrm{NO}_{2}^{-}$level decrease and glutathioperoxidase activity restoration. After CBMA injection angiogenesis activation and the increase in the number of nuclei in the muscle fibrils were observed. The obtained data allow to expand the range of biochemical parameters for assessing the muscles condition after ischemia and indicate a positive effect of platelet-rich plasma and cell bone marrow aspirate injection on skeletal muscle regeneration.

K e y wo rds: ischemia, reperfusion, skeletal muscle, peroxidation, platelet-rich plasma, bone marrow aspirate.

I schemic limb damage is a common problem. Skeletal muscle ischemia usually caused by vascular embolism, traumatic vascular occlusion, and the use of a tourniquet during surgery. Skeletal muscles have low tolerance to ischemia, and the reperfusion period of the ischemic limb is a crucial factor for tissue survival [1].

The permeability of blood vessels increases under ischemia [2], and rheological parameters of the blood change due to increased level of fibrin [3]. Two hours after ischemia-reperfusion (IR) occurs tissue edema [3] and muscle viability decreases by $20 \%$, and after 8 hours by $80 \%$ [4]. The blood flow in the muscles restored after reperfusion, and secondary metabolites, such as oxygen free radicals, fall in the systemic circulation and damage other organs (lung, heart, kidney, liver), which can lead to multiple organ dysfunction [5].

The role of free radicals in the pathogenesis of tissue damage after IR has been widely studied.

(C) 2021 Pidlisetsky A. T. et al. This is an open-access article distributed under the terms of the Creative Commons Attribution License, which permits unrestricted use, distribution, and reproduction in any medium, provided the original author and source are credited. 
Unsaturated fatty acids of cell membranes are a substrate for free radical oxidation in ischemic damaged cells [6]. The superoxide radical causes peroxidation of membrane lipids and proteins, leading to irreversible damage and destruction of skeletal muscle [7]. Damaged vascular endothelial cells and infiltrated in injured tissue leukocytes additionally generate superoxide $\left(\mathrm{O}_{2}^{-}\right)$and $\mathrm{NO}_{2}^{-}$, which form the more toxic peroxynitrite anion (ONOO-). It causes oxidation of lipids, sulfhydryl groups $\left(\mathrm{SH}^{-}\right)$in proteins and nucleic acid damage. The accumulation of IL-1, TNF-1 $\alpha$, IgM and IgG provokes phagocyte migration, development of inflammation and causes muscle hypotrophy [8].

The possibility of using autologous mesenchymal cells to support ischemic damaged tissues is considered. Nowadays, it is easy to obtain a population of bone marrow-derived mononuclear cells that activate angiogenesis and improve blood supply to critically ischemic limb tissues [9]. The bone marrow aspirate contains a mixed population of cells, which includes mainly hematopoietic cells, as well as myogenic and about $2 \%$ of endothelial cells $[10,11]$. Bone marrow-derived mesenchymal cells may increase skeletal muscle regeneration after hypoxia [12], but subsequent work has shown that there is no difference in the action between native and stimulated bone marrow aspirate cells in damaged tissue support [13]. An alternative to autologous concentrated bone marrow aspirate (CBMA) is platelet-rich plasma (PRP), which is often used in traumatology to stimulate regeneration tissues after traumatic injuries [14].

In this work, we focused on biochemical changes in skeletal muscles of the tibia (SMT) after mechanically induced ischemia (MII). Also, we studied these changes after injection of PRP and CBMA in muscles.

\section{Materials and Methods}

Animal model mechanically induced ischemia (MII). The study was carried out on Chinchilla rabbits (weighing 4.2-4.5 kg). All procedures were conducted in accordance with the rules of the Commission on Bioethics of the SI "Institute of Traumatology and Orthopedics of the NAMS of Ukraine (Kyiv, Ukraine) that conforms to the National Institutes of Health Guidelines for Care and Use of Laboratory Animals. Rabbits were housed in standard cages with free access to food and water.
MII was simulated on rabbits $(n=45)$ by medical elastic tourniquet (tourniquet width $5.5 \mathrm{~cm}, 8$ units per limb), from the middle third of the left hind limb the thigh to the ankle joint, thereby immobilized the limb and caused impaired vascular perfusion of the limb. After $6 \mathrm{~h}$, the tourniquet was removed, and animals were divided into 3 experimental groups: 1$)$ the main group $(n=15)$ with MII and injection of saline, 2) the group with MII and injection of autologous PRP (MII + PRP) $(n=15)$, $3)$ the group with MII and injection of autologous CBMA (MII + CBMA) $(n=15)$. The cell suspensions were injected into the upper third of the SMT, once $6 \mathrm{~h}$ after removal of the elastic tourniquet. Experimental animals were removed from the experiment on days 5, 15 and 30 after MII of the limb (5 animals for each period of the experiment). Animals were anesthetized with sodium thiopental at a dose of $60 \mathrm{mg} / \mathrm{kg}$, intraperitoneal. The control group was intact animals $(n=5)$. Thus, 45 rabbits were included in the experiment and divided into 10 groups. All animals were kept under the same conditions.

Autologous concentrated bone marrow aspirate (CBMA). $2 \mathrm{ml}$ of bone marrow were aspirated from the proximal part of the intact femur of a rabbit with $10 \mathrm{G}$ bone puncture needle and $5 \mathrm{ml}$ syringe, like in the article [15]. The aspirate was separated through a Tulip Emulsifier filter (Tulip Medical Products, USA). The aspirate with dextrose citrate coagulate - solution A (1:8) (Baxter C.A., USA/Belgium) was centrifuged for $8 \mathrm{~min}$ at $760 \mathrm{~g}$ and $1.0 \mathrm{ml}$ of supraerythrocytic fraction was collected (the average cell quantity in native aspirate was $55800 / \mathrm{ml}$ ).

Platelet-rich plasma (PRP). Blood was drawn from the ear vein of a rabbit in the amount of $5 \mathrm{ml}$. Whole blood was centrifuged for $8 \mathrm{~min}$ at $760 \mathrm{~g}$ in Arthrex tube (Arthrex ACP $\AA$ Double Syringe System, Arthrex, Inc. USA), and $1 \mathrm{ml}$ of PRP under layer of erythrocytes mass (the average platelet quantity was 928 000/ml) was received.

Histological study. Rabbit SMT samples were fixed in $10 \%$ formalin solution in PBS ( $\mathrm{pH} 7.4)$ for $24 \mathrm{~h}$ at $4^{\circ} \mathrm{C}$. The samples were dehydrated in isopropanol (70\% to $99.8 \%$ ) and embedded in paraffin (Leica Surgipath Paraplast Regular, Formula 'R', Germany). Muscle slides $6 \mu \mathrm{m}$ thick obtained on a Thermo Microm HM 360 microtome (Thermo Fisher Scientific, USA), stained with hematoxylin and eosin and enclosed in a synthetic medium (Merck, Germany). Slices studied on Olympus BX 51 microscope (Olympus Corporation, Japan). 
The lipid peroxidation products assay. Lipid peroxidation was assayed as thiobarbituric acid reactive substances (TBARS) formed as measured by the thiobarbituric acid technique with the Kamyshnikov (2004) method [16] for determining the malondialdehyde (MDA) concentration. Briefly, $2.1 \mathrm{ml}$ tissue homogenate was heated together with $20 \%$ TCA and $0.8 \%$ TBA reagent in boiling water for $10 \mathrm{~min}$. Then the tubes were cooled, and after centrifugation (3,000 g for $10 \mathrm{~min}$ ), the absorbance was measured at $540 \mathrm{~nm}$. TBARS values were expressed in nanomoles of MDA equivalents per milligram of protein [17]. For the estimation of the nitrite level, the Griess reaction was used and performed by method Green [18]. The diene conjugates (DC) level determination was performed in heptane-isopropanol extracts of muscule homogenate by the method described in [19]. SOD was determined spectrophotometrically according to the method of Nishikimi et al. (1972) [20]. The catalase activity (CA) activity was measured by method based on the reaction of undecomposed hydrogen peroxide with ammonium molybdate to produce a yellowish color, which has a maximum absorbance at $374 \mathrm{~nm}$ [21]. The activity of glutathione peroxidase (GP) was determined by accumulation of oxidized glutathione GSSG by the method of Bernchneider, modified by Pereslegina [22]. The levels of oxidized proteins were measured using 2,4-nitrophenylhydrazine (DNPH) [23, 24].

The total protein level assay. The concentration of total protein was measured by the Bradford method [25].

Statistical analysis. Statistical processing of the obtained samples was conducted using the software OriginPro version 8 . The data, presented as mean values $(M) \pm$ standard errors of the means (SEM), were compared using the Kruskal-Wallis test. The differences were considered significant at $P<0.05$.

\section{Results and Discussion}

During the experiment, the MII damage was examined by measuring changes in the activity of SOD, GP and CA, level of $\mathrm{NO}_{2}^{-}$and TBARS in SMT of the rabbits. As seen in Fig. 1 and 2, the activity of SOD and CA was significant increased on day 15 , and CA on day 30 was increased even more.

The activity of GP, on the other hand, decreased vs the activity of CA. It should be noted that a significant decrease in the activity of GP in the rabbit SMT was observed throughout the experiment (Fig. 3).
We associate the enzymatic antioxidant mechanisms with a decrease in the formation of lipid and protein peroxide degradation products (Fig. 4, 5 and 6). Accordingly, no significant changes in the content of DC in the muscles were detected. A significant increase in the content of NO2- (5 times) was detected as early as 5 days after MII, which did not decrease during the entire period of the experiment (Fig. 7).

PRP injection caused activation of SOD and CA on day 5 after MII, and in the next terms, these parameters did not differ from the group with MII. DC level was reduced only on day 5, and TBARS level did not have significant changes vs the MII group.

CBMA injection restored activity of GP and increased activity of CA on day 30 vs the MII group, and did not cause significant changes in the activity of SOD. We noted a significant decrease in $\mathrm{NO}_{2}{ }^{-}$content already on day 5 vs MII group (the same situation in the group with PRP) and did not cause significant changes in the remaining studied biochemical parameters (TBARS, DC, DNPH). The tendency to a reduction in TBARS and DC content (30 day vs 15 day) testified to restore processes.

Analysis of histological studies showed a progressive hypotrophy in rabbit SMT after MII (Fig. 8). The general trend was the interstitial edema, the changes of extracellular matrix, a decrease in the thickness and density of muscle fibers in the muscle samples. The severity and depth of morphological changes depended on the temporal conditions of the experiment. On day 5, ischemic-injured and necrotized muscle fibers, necrotized cells and cell debris in extracellular matrix, and an increase in fibroblast and macrophage density were detected. On day 15 , these changes progressed, and on day 30 , complete destruction of muscle fibers, accumulation of coagulated proteins in the interstitial space and further leukocyte infiltration occurred. The infiltration of monocytes and macrophages was recorded as evidence of inflammation, and the fibroblast reaction was to substitution necrotized muscle fibers by connective tissue. Necrosis of small and medium-sized blood vessels presented on day 5 after ischemia, on day 15 , there were partially restored and an increased density of newly-formed vessels on day 30 of the experiment. After CBMA injection, the trend of hypotrophy in SMT was similar, except for the activation of angiogenesis in subfascial area, and an increase in the number of myonuclei in muscle fibers in deep area of SMT detected (sign of muscle regeneration). 


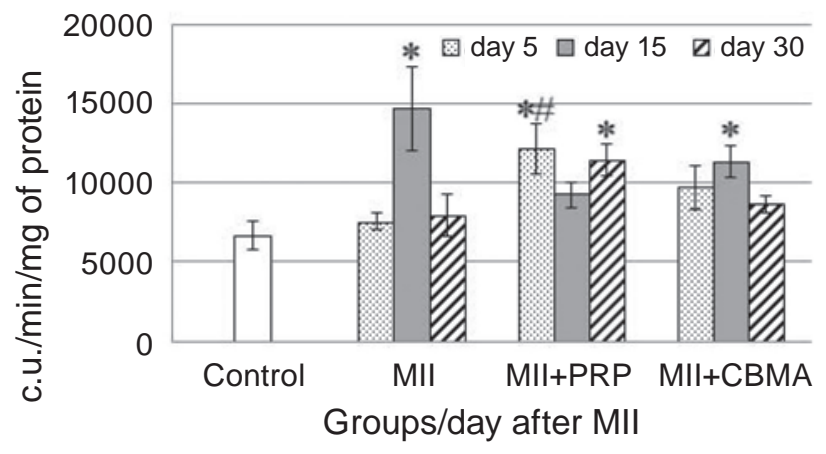

Fig. 1. SOD activity in rabbit $S M T(M \pm S E M, n=5)$. ${ }^{*} P<0.05$ compared with control group; ${ }^{\#} P<0.05$ compared with MII group

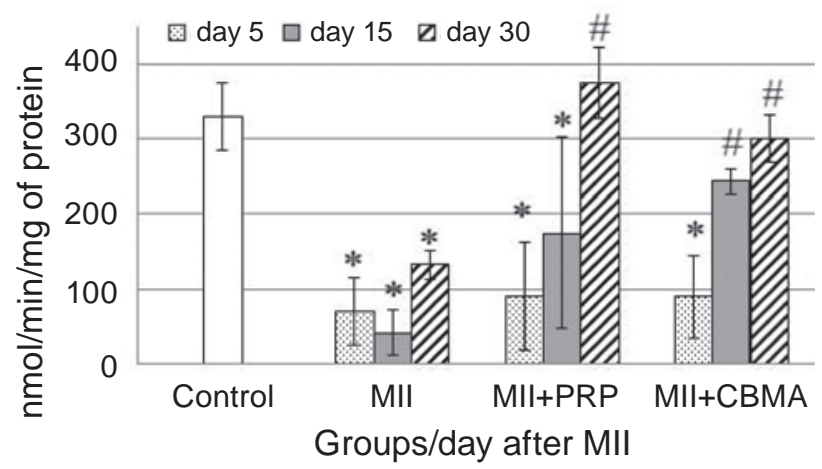

Fig. 3. GP activity in rabbit $\operatorname{SMT}(M \pm m, n=5)$. ${ }^{*} P<0.05$ compared with control group; ${ }^{\#} P<0.05$ compared with MII group

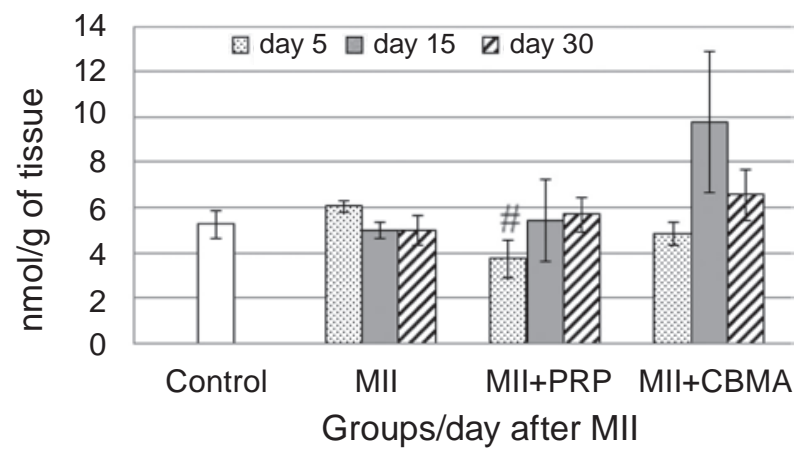

Fig. 5. DC level in rabbit $S M T(M \pm S E M, n=5)$. ${ }^{*} P<0.05$ compared with control group; ${ }^{*} P<0.05$ compared with MII group

The pathogenesis of ischemia-reperfusion injury begins during ischemia and continues after restored blood flow. Acute circulatory hypoxia causes oxygen deficiency, which leads to inhibition of electronic transport in the mitochondrial electron

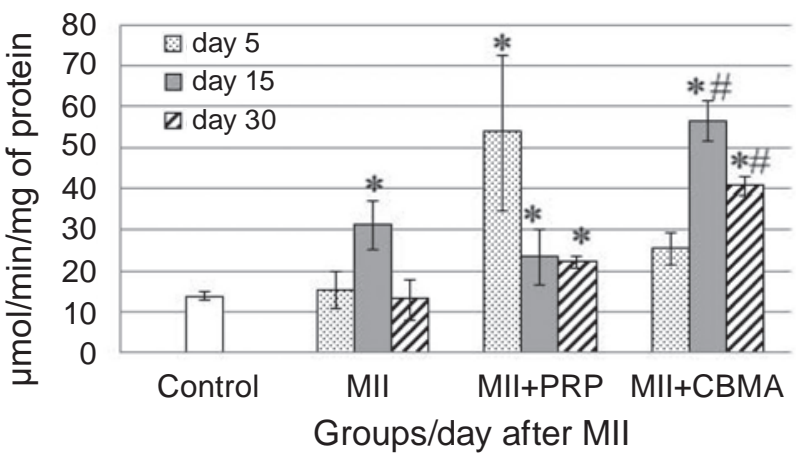

Fig. 2. CA activity in rabbit $S M T(M \pm S E M, n=5)$. ${ }^{*} P<0.05$ compared with control group; ${ }^{\#} P<0.05$ compared with MII group

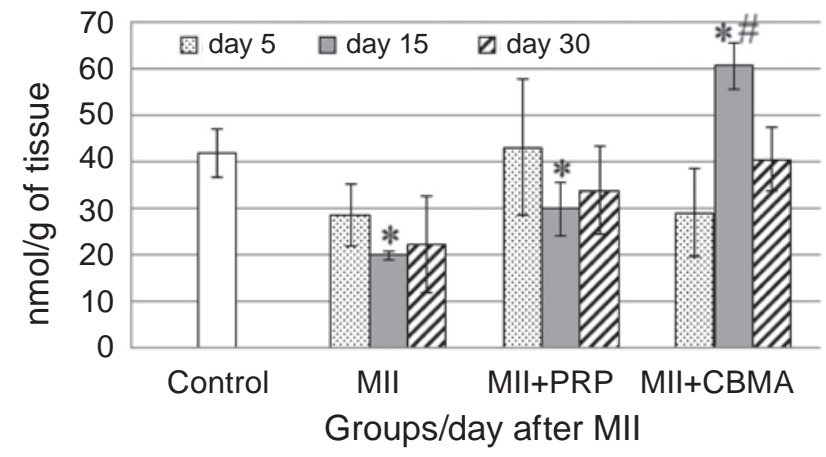

Fig. 4. TBARS level in rabbit $S M T(M \pm S E M, n=5)$. ${ }^{*} P<0.05$ compared with control group; ${ }^{\#} P<0.05$ compared with MII group

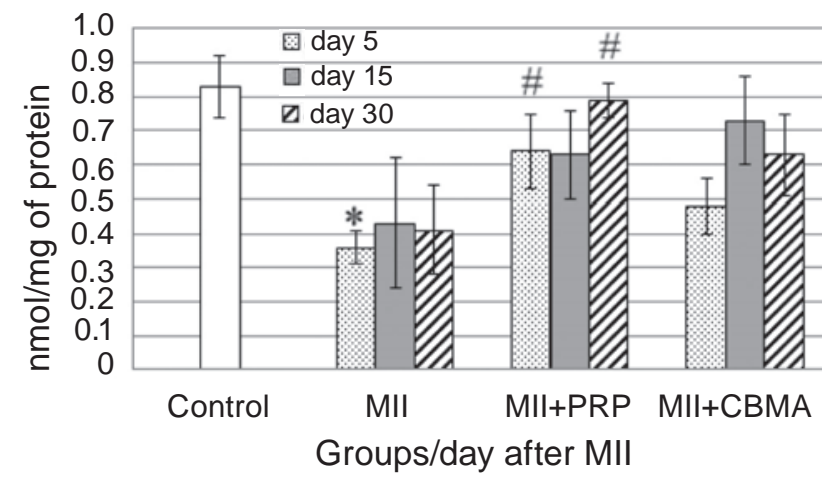

Fig. 6. DNPH level in rabbit SMT $(M \pm S E M, n=5)$. ${ }^{*} P<0.05$ compared with control group; ${ }^{\#} P<0.05$ compared with MII group

transport chain and significantly limits the formation of macroergic compounds (ATP, creatine phosphate) in the cells of damaged tissues (muscle, endothelial, fibroblasts). This leads to disruption of the $\mathrm{Na}^{+} / \mathrm{K}^{+}-$ pump, membrane depolarization and intracellular 


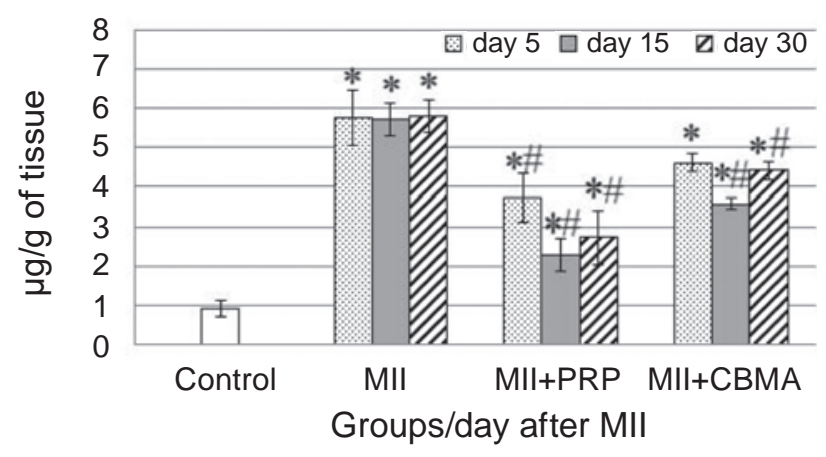

Fig. 7. $\mathrm{NO}_{2}^{-}$level in rabbit $S M T(M \pm S E M, n=5)$. ${ }^{*} P<0.05$ compared with control group; ${ }^{\#} P<0.05$ compared with MII group

$\mathrm{Ca}^{2+}$ accumulation [26]. The increase in cytoplasmic and intramitochondrial concentration of $\mathrm{Ca}^{2+}$ ions, according to modern ideas, is one of the leading mechanisms of ischemic damage, as it leads to mitochondrial dysfunction and activation of a cascade of $\mathrm{Ca}^{2+}$-dependent enzymatic systems that cause the destruction of biological membranes and inflammation [27]. The severity of IR injury directly depends on the duration of the ischemia period. In ischemiainjured muscle, the threshold for stimulation, which is necessary to achieve the maximum level of contraction, is sharply reduced. The muscle contraction reaches zero level after 90-100 min of the ischemia and [28]. Acute ischemia leads to changes in the structure of muscle fibers. As a result, the muscle is unable to maintain a steady state of contraction [29]. Restoration of blood flow (reperfusion period) is characterized by further damage to ischemic tissues. The leading role is played by reactive forms of oxygen (ROS), formed in the mitochondrial electron transport chain from accumulated nicotinamide adenine dinucleotide $\left(\mathrm{NADH}^{+}\right)$during ischemia. Studies of mitochondrial function have shown two-phase modulation of electron transfer activity and electron transport chain protein expression during IR: that the activity of complexes I, II, III and IV decreased after ischemia but increased after restoring blood flow [26]. An important role in the detoxification of excess ROS is played by enzymes of antioxidant protection (AOP). The activity of these enzymes directly affects the degree of damage to the muscle tissue of IR injury and the duration of its recovery.

The changes in the activity of AOP enzymes in muscle tissue during IR injury and in the first hours after it are well studied and described in the articles [29-31]. The subject of our research was to study the activity of major AOP enzymes and the content of lipid and protein peroxide degradation products in the muscle tissue of the rabbit SMT at more distant time periods, namely 5, 15 and 30 days after MII (as IR injury), and to assess the possible therapeutic effect of autologous CBMA.

The results of our studies of the activity of the main AOP enzymes SOD and CA showed a probable increase in their activity in the IP-injured muscle of the rabbit SMT on the $15^{\text {th }}$ day of the experiment. At the same time, the activity of GP, on the contrary, decreased significantly. It is known that GP is activated in the presence of low amounts of peroxide and lipoperoxides, while at high concentrations of hydrogen peroxide, the CA is activated [26].

Thus, we contend that the overproduction of ROS continues in injured muscles in the longer term after MII. However, the analysis of the level of lipid and protein peroxide degradation products (TBA-active compounds, DC and DNPH derivatives) indicate that ROS is "neutralized" by AOP enzymes [32]. At the same time, the consistently high content of $\mathrm{NO}_{2}{ }^{-}$ (5 times higher than normal) during the whole period of the experiment attracts attention. It is well known that NO plays an important role as an endothelial relaxation factor in the regulation of hemodynamics, however, its excessive production under reoxygenation conditions can contribute to the formation of toxic peroxynitrite (ONOO-), thereby reducing the bioavailability of NO itself and increasing. Peroxynitrite is further metabolized (oxidized) to nitrite $\left(\mathrm{NO}_{3}^{-}\right)$, which can be reduced to $\mathrm{NO}$ by nitrite reductases (NiR) [33]. Therefore, the content of $\mathrm{NO}_{2}{ }^{-}$is an integral factor that indicates the direction of changes in the production of $\mathrm{NO}$ in cells. It should be noted that in our studies, the high content of $\mathrm{NO}_{2}{ }^{-}$in the IR-injured rabbit SMT remained until the end of the experiment, i.e. for 30 days. This fact may indicate an inflammatory process and the involvement of the inducible isoform of NO synthase (iNOS) in the formation of a pool of $\mathrm{NO}_{2}^{-}$in muscle tissue after IR injury. The inflammatory process that develops as a result of mass cell death by necroptosis, as was confirmed by histological studies, involves the infiltration of leukocytes and macrophages in the inflammatory focuses, and NO, that produced by these cells, can promote the growth of a pool of $\mathrm{NO}_{2}^{-}$in damaged muscle tissue.

Today, the use of PRP and CBMA is becoming increasingly popular among methods of regenerative medicine. PRP, prepared from autologous whole 

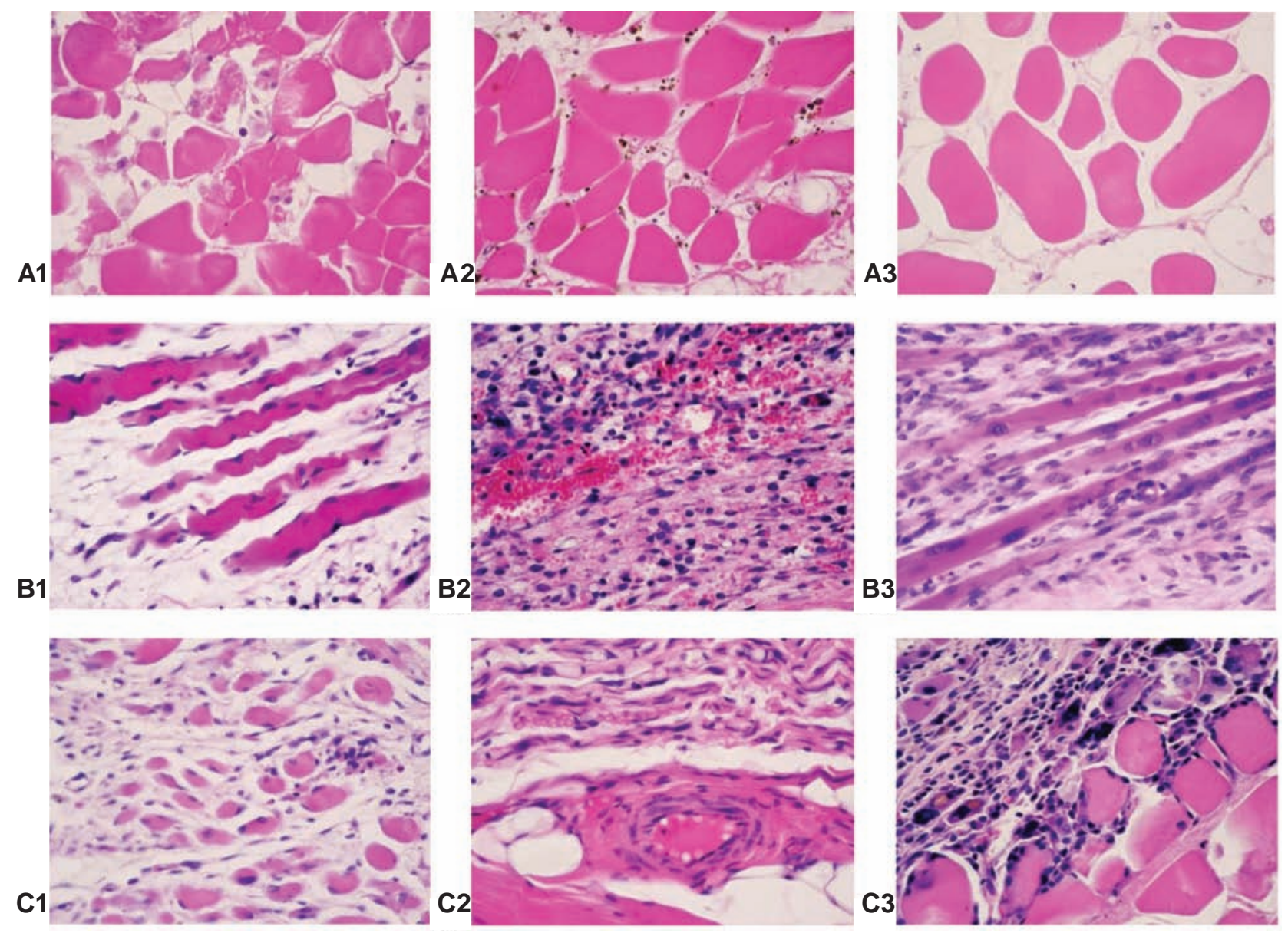

Fig. 8. Rabbit SMT morphology after MII: interstitial edema and muscle fibers atrophy. Note: $\boldsymbol{A}$ - day 5 after MII; B - day 15 after MII; $\boldsymbol{C}$ - day 30 after MII; 1 - MII; 2 - MII + PRP; 3 - MII + CBMA. Hematoxylin and eosin stain, original magnification $\times 400$

blood, contains a supraphysiological concentration of platelets, which excrete various growth factors in tissues (TGF $\beta-1$, PDGF, FGF-2 etc.) [14]. PRP promote muscle healing and can decrease pro-inflammatory reaction and cell apoptosis in injured skeletal muscle [34]. The CBMA include hematopoietic progenitor cells and mesenchymal stem cells, growth factors and cytokines, which initiate the tissue's own mechanisms for regeneration, in particular, cartilage, bones, tendons [35].

Summarising the data, we suggest that PRP and CBMA application in this experiment resulted in modulation of the activity of AOP enzymes in rabbit SMT after MII. The activity of SOD approached the control values, while the activity of CA increased significantly and remained quite high until the end of the experiment. The reaction of AOP enzymes to PRP was more pronounced in acute post-injury pe- riod. The most pronounced effect of PRP and CBMA was a reduction in $\mathrm{NO}_{2}^{-}$level in all experimental period, which may indirectly indicate the anti-inflammatory effect of autologous treatment and stimulation to recovery. Given the multicomponent nature of PRP and CBMA, it is difficult to give a definitive answer about the specific biochemical mechanisms of its therapeutic and prophylactic action. We can only speculatively assume the role of the cytokine system of these injections in reducing the inflammatory process in the IR-injured rabbit SMT in the long term.

Conclusion. The experimental MII of SMT caused oxidative stress through overproduction of $\mathrm{NO}_{2}{ }^{-}$, reduction of TBA-active products and DNPH and AOP system response (enhance SOD, and CA activity on day 15 , prolonged decrease GP activity). Injection of PRP and CBMA to rabbit's SMT with 
MII contributed to the utilization of $\mathrm{NO}_{2}{ }^{-}$and partial restoration of enzymatic AOP system.

Conflict of interest. The authors have completed the Unified Conflicts of Interest form at http:// ukrbiochemjournal.org/wp-content/uploads/2018/12/ coi_disclosure.pdf and declare no conflict of interest.

Acknowledgments. The study was supported by the topic of SI "Institute of Traumatology and Orthopedics under NAMS of Ukraine" "Develop technology for treatment and rehabilitation of patients with combat polystructural injury of the extremities”.

\section{ВВЕДЕННЯ ЗБАГАЧЕНОЇ ТРОМБОЦИТАМИ ПЛАЗМИ АБО КОНЦЕНТРОВАНОГО КЛІТИННОГО АСПІРАТУ КІСТКОВОГО МОЗКУ ПІСЛЯ МЕХАНІЧНОІНДУКОВАНОЇ ІШЕМІЇ ПОКРАЩУЄ БІОХІМІЧНІ ПОКАЗНИКИ В СКЕЛЕТНИХ М'Я3АХ}

\author{
А. Т. Підлісеиькийㅁ, Г. В. Косякова ${ }^{2}$, \\ T. М. Горідько ${ }^{2}$, А. Г. Бердишев ${ }^{2}$, \\ О. Ф. Мегедь ${ }^{2}$, С. I. Савосько ${ }^{3 凶, ~}$ \\ О. В. Долгополов ${ }^{4}$
}

\footnotetext{
${ }^{1}$ Львівський обласний госпіталь ветеранів війни та репресованих імені Ю. Липи, Україна; ${ }^{2}$ Інститут біохімії ім. О. В. Палладіна НАН України, Київ;

${ }^{3}$ Національний медичний університет імені О.О. Богомольця, Київ, Україна ${ }^{4} Д У$ «Інститут ортопедії та травматології НАМН України», Київ;

凶e-mail: savosko_s@ukr.net
}

Відомо, що механічна ішемія спричинює структурні й функціональні пошкодження скелетних м'язів. У цьому дослідженні для покращення стану м'язів після ішемії використано збагачену тромбоцитами плазму (ЗТП) та аспірат кісткового мозку (АКМ), які вважаються перспективними для застосування у відновлювальній медицині. Механічноіндуковану ішемію (МII) скелетних м'язів кроля спричинювали накладанням джгута на задню кінцівку протягом 6 годин, після чого джгут видаляли, через 6 год одноразово вводили в гомілку кролячі ЗТП чи АКМ та поділяли тварин на експериментальні групи $(n=15): 1$ - ішемія+фізіологічний розчин, 2 -ішемія + 3ТП, 3 - ішемія + АКМ. Контрольна група - інтактні тварини $(n=5) .3$ експерименту кролів видаляли на 5, 15 і 30 добу реперфузії після ішемії. Показано, що ішемія м'язів гомілки спричинювала прогресивну гіпотрофію, руйнування м'язових волокон та лейкоцитарну інфільтрацію. Гіпотрофічний стан супроводжувався активацією каталази і супероксиддисмутази, тривалою гіперпродукцією $\mathrm{NO}_{2}^{-}$та значним зниженням активності глутатіон пероксидази в гомогенатах м'язів. Після локального введення ЗТП та АКМ в ішемізований м'яз активність каталази залишалась на підвищеному рівні, проте активність СОД наближалась до контрольного рівня, а найвиразнішим виявилось зниження рівня $\mathrm{NO}_{2}^{-}$та відновлення активності глутатіонпероксидази. Після ін'єкції АКМ виявлено активацію ангіогенезу та збільшення кількості ядер у м'язових фібрилах. Одержані дані дозволяють розширити спектр біохімічних показників для оцінки стану м'язів після ішемії та свідчать про позитивний вплив ЗТП і АКМ на регенерацію скелетних м'язів.

Кл ю чов і слова: ішемія, реперфузія, скелетні м'язи, пероксидація, збагачена тромбоцитарна плазма, аспірат кісткового мозку.

\section{References}

1. Siemionow M, Arslan E. Ischemia/reperfusion injury: a review in relation to free tissue transfers. Microsurgery. 2004; 24(6): 468-475.

2. Drysch M, Wallner C, Schmidt SV, Reinkemeier F, Wagner JM, Lehnhardt M, Behr B. An optimized low-pressure tourniquet murine hind limb ischemia reperfusion model: Inducing acute ischemia reperfusion injury in C57BL/6 wild type mice. PLoS One. 2019; 14(1): e0210961.

3. Duehrkop C, Rieben R. Refinement of tourniquet-induced peripheral ischemia/reperfusion injury in rats: comparison of $2 \mathrm{~h}$ vs $24 \mathrm{~h}$ reperfusion. Lab Anim. 2014; 48(2): 143-154.

4. Cunha MS, da Silva JC, Nakamoto HA, Ferreira MC. Study of warm ischemia followed by reperfusion on a lower limb model in rats: effect of allopurinol and streptokinase. Clinics (Sao Paulo). 2005; 60(3): 213-220.

5. Yassin MM, Harkin DW, Barros D'Sa AA, Halliday MI, Rowlands BJ. Lower limb ischemia-reperfusion injury triggers a systemic inflammatory response and multiple organ dysfunction. World J Surg. 2002; 26(1): 115-121. 
6. Ekinci Akdemir FN, Gülçin İ, Karagöz B, Soslu R, Alwasel SH. A comparative study on the antioxidant effects of hesperidin and ellagic acid against skeletal muscle ischemia/ reperfusion injury. $J$ Enzyme Inhib Med Chem. 2016; 31(sup4): 114-118.

7. Kılıç Y, Özer A, Tatar T, Zor MH, Kirişçi M, Kartal H, Dursun AD, Billur D, Arslan M, Küçük A. Effect of picroside II on hind limb ischemia reperfusion injury in rats. Drug Des Devel Ther. 2017; 11: 1917-1925.

8. Bianco-Batlles MD, Sosunov A, Polin RA, Ten VS. Systemic inflammation following hind-limb ischemia-reperfusion affects brain in neonatal mice. Dev Neurosci. 2008; 30(6): 367373.

9. Ismail AM, Abdou SM, Aty HA, Kamhawy AH, Elhinedy M, Elwageh M, Taha A, Ezzat A, Salem HA, Youssif S, Salem ML. Autologous transplantation of CD34(+) bone marrow derived mononuclear cells in management of nonreconstructable critical lower limb ischemia. Cytotechnology. 2016; 68(4): 771-781.

10. Liew A, O'Brien T. Therapeutic potential for mesenchymal stem cell transplantation in critical limb ischemia. Stem Cell Res Ther. 2012; 3(4): 28.

11. Elshaer SL, Lorys RE, El-Remessy AB. Cell therapy and critical limb ischemia: evidence and window of opportunity in obesity. Obes Control Ther. 2016; 3(1): 121.

12. Leroux L, Descamps B, Tojais NF, Séguy B, Oses $\mathrm{P}$, Moreau $\mathrm{C}$, Daret $\mathrm{D}$, Ivanovic $\mathrm{Z}$, Boiron JM, Lamazière JMD, Dufourcq $P$, Couffinhal T, Duplàa C. Hypoxia preconditioned mesenchymal stem cells improve vascular and skeletal muscle fiber regeneration after ischemia through a Wnt4-dependent pathway. Mol Ther. 2010; 18(8): 1545-1552.

13. Rosová I, Link D, Nolta JA. shRNA-mediated decreases in c-Met levels affect the differentiation potential of human mesenchymal stem cells and reduce their capacity for tissue repair. Tissue Eng Part A. 2010; 16(8): 2627-2639.

14. Setayesh K, Villarreal A, Gottschalk A, Tokish JM, Choate WS. Treatment of muscle injuries with platelet-rich plasma: a review of the literature. Curr Rev Musculoskelet Med. 2018; 11(4): 635-642.

15. Gaiovych I, Savosko S, Labunets I, Utko N, Makarenko A, Chaikovsky Y. Sciatic nerve regeneration after autografting and application of the bone marrow aspirate concentration. Georgian Med News. 2019; (295): 145-152.

16. Kamyshnikov VS. Reference Book on Clinic and Biochemical Researches and Laboratory Diagnostics. Moscow: MEDpress-inform, 2004 (In Russian).

17. Gulaya NM, Kuzmenko AI, Margitich VM, Govseeva NM, Melnichuk SD, Goridko TM, Zhukov AD. Long-chain N-acylethanolamines inhibit lipid peroxidation in rat liver mitochondria under acute hypoxic hypoxia. Chem Phys Lipids. 1998; 97(1): 49-54.

18. Green LC, Wagner DA, Glogowski J, Skipper PL, Wishnok JS, Tannenbaum SR. Analysis of nitrate, nitrite, and [15N]nitrate in biological fluids. Anal Biochem. 1982; 126(1): 131-138.

19. Volchegorsky IA, Nalimov AG, Yarovinsky BG, Lifshitz RI. Different means of lipid peroxidation products estimation in heptane-isopropanol extracts of blood. Vopr Med Chim. 1989; 25(1): 127-131.

20. Nishikimi M, Appaji N, Yagi K. The occurrence of superoxide anion in the reaction of reduced phenazine methosulfate and molecular oxygen. Biochem Biophys Res Commun. 1972; 46(2): 849-854.

21. Hadwan MH, Abed HN. Data supporting the spectrophotometric method for the estimation of catalase activity. Data Brief. 2015; 6: 194-199.

22. Pereslegina IA. The activity of antioxidant enzymes in the saliva of normal children. $L a b$ Delo. 1989; (11): 20-23. (In Russian).

23. Oliver CN, Ahn BW, Moerman EJ, Goldstein S, Stadtman ER. Age-related changes in oxidized proteins. J Biol Chem. 1987; 262(12): 5488-5491.

24. Weber D, Davies MJ, Grune T. Determination of protein carbonyls in plasma, cell extracts, tissue homogenates, isolated proteins: Focus on sample preparation and derivatization conditions. Redox Biol. 2015; 5: 367-380.

25. Bradford MM. A rapid and sensitive method for the quantitation of microgram quantities of protein utilizing the principle of protein-dye binding. Anal Biochem. 1976; 72: 248-254.

26. Soares ROS, Losada DM, Jordani MC, Évora P, Castro-E-Silva O. Ischemia/reperfusion injury revisited: an overview of the latest pharmacological strategies. Int J Mol Sci. 2019; 20(20): 5034.

27. Paradis S, Charles AL, Meyer A, Lejay A, Scholey JW, Chakfé N, Zoll J, Geny B. Chrono- 
logy of mitochondrial and cellular events during skeletal muscle ischemia-reperfusion. $\mathrm{Am} J$ Physiol Cell Physiol. 2016; 310(11): C968-C982.

28. Nozdrenko DM, Soroka VM, Khoma OM. Kinetics of single contractions inhibition under ischemia-reperfusion as an indicator of $\mathrm{m}$. gastrocnemius functional state in rats. Fiziol $\mathrm{Zh}$. 2019; 65(1): 50-56.

29. Dolgopolov OV, Nozdrenko DM, Strafun SS, Miroshnichenko MS. A change of skeletal muscles contraction parameters during the sharp ischemia. Physics Alive. 2010; 18(3): 64-69.

30. Tran TP, Tu H, Pipinos II, Muelleman RL, Albadawi H, Li YL. Tourniquet-induced acute ischemia-reperfusion injury in mouse skeletal muscles: Involvement of superoxide. Eur $J$ Pharmacol. 2011; 650(1): 328-334.

31. Dong X, Xing Q, Li Y, Han X, Sun L. Dexmedetomidine protects against ischemiareperfusion injury in rat skeletal muscle. $J$ Surg Res. 2014; 186(1): 240-245.
32. Televiak AT, Veresiuk TO, Selskyy PR, Volska AS, Kurylo KI, Nebesna ZM, Datsko TV, Boymystruk II. Dynamic ofindices of lipid peroxidation and antioxidant protection in muscular tissue and blood serum of rats with acute ischemia-reperfusion. $J$ Educ Health Sport. 2018; 8(10): 245-255.

33. DeMartino AW, Kim-Shapiro DB, Patel RP, Gladwin MT. Nitrite and nitrate chemical biology and signalling. Br J Pharmacol. 2019; 176(2): 228-245.

34. Tsai WC, Yu TY, Chang GJ, Lin LP, Lin MS, Pang JHS. Platelet-Rich Plasma Releasate Promotes Regeneration and Decreases Inflammation and Apoptosis of Injured Skeletal Muscle. Am J Sports Med. 2018; 46(8): 19801986.

35. Xie X, Wang Y, Zhao C, Guo S, Liu S, Jia W, Tuan RS, Zhang C. Comparative evaluation of MSCs from bone marrow and adipose tissue seeded in PRP-derived scaffold for cartilage regeneration. Biomaterials. 2012; 33(29): 70087018. 